\title{
Sediment as a dynamic natural resource-from catchment to open sea
}

\author{
Jasmina Obhodas ${ }^{1}$. Elena Romano ${ }^{2} \cdot$ Marta Castellote $^{3} \cdot$ Susanne Heise $^{4}$ \\ Published online: 6 May 2020 \\ (C) Springer-Verlag GmbH Germany, part of Springer Nature 2020
}

\section{Introduction}

It is our privilege and honour to introduce this special issue which emphasises the importance of sediment studies for tackling problems of pollution and global climate change impacts but also points to the economic value of sediments. The presented papers are the result of a rigorous selection of studies presented by 160 participants at the 11th SedNet conference which took place in Dubrovnik, Croatia, from 3 to 5 April, 2019. The SedNet organization is always eager to present the most relevant and most recent topics related to sediment issues of importance for scientists, practitioners, and decision makers. At the SedNet 2019 conference, considering that the prospecting and exploration of sea depths greater than $1000 \mathrm{~m}$ has become a fast emerging field, a topic on deep-sea sediments was included for the first time, and this is reflected in the title of the special issue. The other topics included in the SedNet 2019 conference were (1) sediment management and sediment policy; (2) sediment quality guidance, sediment quality assessment; (3) sediments in ecosystem services provision; (4) direct and indirect consequences for sediments due

Jasmina Obhodas

jobhodas@irb.hr

Elena Romano

elena.romano@isprambiente.it

Marta Castellote

martaca@ietcc.csic.es

Susanne Heise

susanne.heise@haw-hamburg.de

1 Ruđer Boskovic Institute, Bijenicka c.54, Zagreb, Croatia

2 ISPRA, Italian Institute for Environmental Protection and Research, Rome, Italy

3 Institute of Construction Science Eduardo, Torroja (IETcc-CSIC), Madrid, Spain

4 Hamburg University of Applied Sciences, Hamburg, Germany to climate change; (5) circular economy and sediment as a resource; (6) societal impacts of disturbed sediment continua and mitigation measures; (7) the impact and transport of microplastics; (8) ballast water and sediments-BWM Convention; and (9) nuclear and isotopic analytical techniques in sediment analysis (sponsored by the International Atomic Energy Agency). We are glad that we can distribute to a wider community some of the most interesting results of the presented studies. There were other very relevant studies presented, but it was not possible to include them all in this volume. Thus, the selection of papers represents the cross-section of included topics that have passed the rigorous peer review process, but unavoidably reflects the personal tastes of the editorial team as well. We hope the readers will gladly use the results of 20 selected papers published in this volume to gain further knowledge and understanding in their fields of work. A brief introduction of the selected papers is given below.

\section{Sediment management and sediment policy}

Echo-sounders are conventional instruments for surveying the nautical bottom in ports but they work properly if there is a sharp interface between the water column and sediment bed. A thick fluid layer of mud, which blurs the sediment bed and can jeopardize navigation when the ship's keel comes in its vicinity, can overlay the nautical bottom. Kirichek et al. (2020) have taken a different approach to characterise the nautical bottom which does not show a sharp sedimentwater interface. They have used recently developed vertical profilers (Graviprobe and Rheotune) for in-situ measurements of mud density and yield stress as criteria to assess the thickness of the fluid mud layer and depth of the nautical bottom. The results obtained by in-situ measurements were compared with laboratory rheological measurements and a model that predicts the consolidation of weak mud. The authors showed that the correlation between density and yield stress measurements, as a function of different measuring equipment, 
strongly depends on the type of mud. To work properly, instruments have to be calibrated according to a mud type. The authors concluded that the development of a model that accurately predicts the sediment consolidation time is necessary to decrease the workload.

Shakeel et al. (2020) propose an innovative way to define navigable fluid mud layers based on their rheological properties, in particular their yield stress. They investigated the changes in the rheological properties of mud from along the river stream in the Port of Hamburg, Germany. A variety of rheological tests have been performed including stress sweep tests, flow curves, thixotropic tests, oscillatory amplitude, and frequency sweep tests. As a result, the applicability of a recently developed protocol as a fast and reliable tool to measure the yield stress of sediment has been confirmed.

The information on the physical and biogeochemical dynamics of deep-sea sediments is important for understanding the large-scale dispersion of contaminants, as shown by Tamburrino et al. (2020). Italy has legally designated several sites of national relevance (SIN) aimed for remediation. By examining the existing datasets on concentration levels of different organic and inorganic pollutants within and around three coastal SIN locations, which are highly contaminated former industrial sites, the authors have demonstrated the need for determining the buffer zones around SIN. The buffer zones will protect the deep-sea sediments from the delivery of contaminants and their further spreading into the wider marine environment and trophic chain.

Microbial degradation of organic matter in sediments may interfere in a number of ways with dredged material management activities in ports. Zander et al. (2020) investigated the spatial variability of sediment organic matter degradability in the Port of Hamburg. They found an inverse relationship of lability and stabilisation in organomineral complexes and were able to identify vertical and horizontal distribution patterns that reflected the origin and age of the organic matter.

\section{Sediment quality guidance, sediment quality assessment}

Baran et al. (2019) present a study that assessed the levels of persistent organic contaminants such as polychlorinated dibenz-p-dioxin and polychlorinated dibenzofuran (PCDD/Fs) in lake sediments of the coal mining and highly industrial region in Poland. PCDD/F concentrations in the sediment samples were 2- to 38 -fold higher than the sediment quality guidelines limits, indicating high ecological risk potential. The sources of distribution were combustion processes, transport, wastewater discharge, hightemperature processes, and thermal electricity generation.
The silt/clay fraction played a dominant role in the movement of PCDDs/Fs, while the organic matter fraction affected their sorption. The results were compared with sediments of similar urban and industrial regions worldwide.

Joksimović et al. (2020) describe a regional study that tackles pollution levels of Montenegrian coastal and open sea sediments by determining the concentrations of 10 metals and metalloids ( $\mathrm{Fe}, \mathrm{Mn}, \mathrm{Zn}, \mathrm{Cu}, \mathrm{Ni}, \mathrm{Pb}, \mathrm{Cr}, \mathrm{Cd}$, As, and $\mathrm{Hg}$ ) during the period 2005-2016. Pollution status was evaluated using the contamination factor, pollution load index, and geo-accumulation index, as well as statistical methods, such as the Pearson correlation coefficient and cluster analysis. The calculated concentration factor and pollution load index indicated enrichment by either natural processes or anthropogenic influences. However, the geo-accumulation index and pollution load index showed that the metal levels at some locations were high enough to pose a risk to the ecosystem.

Sediments are considered waste according to French regulations and have to be classified as non-hazardous, before their beneficial usage. Among the 15 hazard properties that sediments have to be tested against, HP14 assesses ecotoxicity. Lecomte et al. (2020) extended the typical biotest battery by additional test systems and modified the test approach, using up-flow percolation columns. They succeeded in differentiating sediments that were categorised as non-hazardous on the basis of low ecotoxic responses, therewith improving the safety of their beneficial use.

A paper by Lehoux et al. (2020) is focused on the comparison between different approaches used in four Nordic countries (Sweden, Norway, Finland, and Denmark) for the assessment, regulation, and remediation of contaminated marine sediments. This review is of great interest in light of the need for harmonising methods for assessment of sediment status and their remediation. It highlighted: the need of a characterization survey for a better assessment of the pollution level; the importance of monitoring the long-term effects after remediation operations; and suggests a common Nordic database of clean-up remediation projects to improve the exchange of knowledge between the Nordic countries and the international community, and to harmonise guidelines for contaminated sediment handling.

Romano et al. (2020) compared chemical data and ecotoxicological responses to sediments that had been heavily contaminated by long-lasting mining activities with the aim to identify a reliable approach for the characterisation of sediment quality. Despite sequential extractions indicating the mobility of heavy metals, the marine biotests applied did not give positive responses. The authors concluded that bioassays as such could not replace chemical analysis and could be complemented with bioaccumulation data, biomarker studies, and the assessment of the benthic community. 


\section{Direct and indirect consequences for sediments due to climate change}

Szalińska et al. (2020) applied a Discharge-Nutrient-Sea/Soil Water Assessment model to analyse the variability of sediment loads under varying climate change and land-use scenarios in a Carpathian catchment with a dam reservoir. Their results demonstrate the importance of elevated erosion during warm winters with heavy rainfalls, resulting in increased sediment loads which could be mitigated by an increase in forest cover.

\section{Circular economy and sediment as a resource}

The research of effective and cheap methods for the remediation of contaminated sediments is a topic of high interest not only from a scientific, but also an economic and management viewpoint. The paper by Cecchi et al. (2020) describes the possibility of using bio-membranes, obtained by the growth of fungi on microporous supports, for the remediation of contaminated sediments in four different Italian sites. The results in the different sites showed different degrees of metals' bioaccumulation by fungi mainly due to environmental conditions, the physical characteristics of sediments, and the different fungal species used.

Garcia-Blas et al. (2020a) explored the dynamics between the matrix of polluted marine sediments, type of contaminants and various desorbing solutions considering equilibrium tests, sedimentation trials, and zeta potential with the focus on assessing optimum enhancing solutions for decontamination purposes. The sediment, mainly composed of clay and lime and containing high concentrations of iron, demonstrated a strong influence on sorption-desorption processes. The most important parameters for contaminants release are the complexation ability of the solution for the sediment components and $\mathrm{pH}$ of the solution. These results could be of importance for the management of sediments.

Garcia-Blas et al. (2020b) used the electrokinetic technique to remove the increased concentrations of heavy metals and organic contaminants from raw marine sediment dredged from a harbour. Laboratory size experimental configurations included carbon steel or titanium electrodes. Tests were performed with the addition of acid or hydrogen peroxide to catholyte in order to enhance mobilisation of metals. The authors measured the current density, $\mathrm{pH}$, conductivity, electroosmotic flow, and zeta potential carrying out the thermal gravimetric analysis to assess the remediation rate. The sediments were characterised before and after the treatment, whereas the concentrations of metals and organic contaminants in electrolytes were periodically analysed during the conduction of experiments. The sediment showed a high buffering capacity hindering the formation of acid front and electroosmotic flow indicated as important for the successful removal of contaminants. The best results were observed when using titanium electrodes with the addition of acid. A 30\% removal of $\mathrm{Zn}$ was observed, and most of it was extracted from sediment within the first $24 \mathrm{~h}$.

\section{Societal impacts of disturbed sediment continua and mitigation measures}

Pellegrini et al. (2020) present results of the MARINAPLAN PLUS LIFE project, with the aim to demonstrate the effectiveness of a novel sediment by-passing technology as an alternative to dredging fine sediments. The first promising results are reported and the plans for the demonstration plant design are explained. With the project now entering the decisive phase, surveys are planned to study the environmental impact as well as operation and maintenance costs during operation in order to compare them to dredging activities.

The effects of river infrastructures on the floodplain sedimentary environment in the Rhône River were studied by Vauclin et al. (2020) taking into account 15 sediment cores and their textural characteristics in three different reaches of the Rhône valley downstream of Lyon, France. The results highlighted a sharp change in grain-size distribution due to an abrupt decrease in connectivity between the floodplain and the river channel, likely due to the implementation of navigation infrastructures in the channel in the second half of the nineteenth century. In one case, the dating of the sediment cores allowed the authors to link the change in grain-size to the implementation of navigation infrastructures in the channel.

Dredged sediments are often used for the construction of roads and dikes, for the production of concrete, and for agricultural spreading. Utilisation of dredged sediments saves the storage costs. On the other hand, the costs of transportation and their remediation up to the environmental and technical standards, should be considered. Zeraoui et al. (2020) developed and presented software that proposes an optimal solution that meets the different environmental and technical requirements of sediment utilisation at a lower cost. The software takes into consideration environmental and technical constraints imposed by legal regulations for each type of application. The economical aspects take into account cost assessment related to dredging operations, natural materials used for mixing, remediation treatment, and transportation. The software computation model has been validated using a road construction project in Lille, France. The results confirmed the reliability of the solution proposed by the software. 


\section{Ballast water and sediments-BWM convention}

Amongst the greatest threats to coastal and marine environments around the world are aquatic invasive alien species (IAS) and harmful aquatic organisms and pathogens (HAOP). Valkovic and Obhodas (2020) investigated this problem concerning sediments in the ship's ballast water tank in the framework of the International Maritime Organization's (IMO) International Convention for the Control and Management of Ships' Ballast Water and Sediments, which was entered into force in September 2017. The state of the art has been summarised, and requirements for sediment management procedures have been discussed and proposed for their implementation.

\section{Deep-sea sediments}

The important subject of the role of deep-sea sediments in producing methane hydrates (MHs) is undertaken in the paper by Obhodas et al. (2020). In addition to the enormous unconventional reservoir of methane worldwide, their role in the global climate change is also considered. The study focuses on the evaluation of the environmental conditions in the deep Adriatic Sea during the last glacial maximum and presently with respect to the potential occurrence of MHs. It has been shown that the deep-sea temperature of the Adriatic Sea has increased by for almost $1^{\circ} \mathrm{C}$ since the 1960s. Calculated phase stability diagrams for the Adriatic Sea results have shown that MHs reservoir in the deep-sea basin exhibit boundary instability for MHs occurrence, which might be of importance for studying the role of MHs in climate change.

\section{Nuclear and isotopic analytical techniques in sediment analysis}

The mainly analytical-methodological article by Knežević et al. (2020) is focused on the improvement of an already published method for the speciation of vanadium (V) in different types of sediment, in particular to determine the species V(IV) and V(V), through ion-exchange chromatography with a UV-VIS detector. The results highlighted the prevalence of the less soluble fraction of this metal in the estuary sediments while the acid-extractable fraction comprised approximately $40 \%$ of the total vanadium present; in contrast, open sea sediment was completely dominated by acid-extractable vanadium. The methodology, even if at a preliminary stage, is demonstrated be a promising analytical method for vanadium speciation.

Historical trends in sea primary production and carbonate precipitation have been analysed by Vinković et al. (2020) by measurement of carbon in undisturbed sediment cores by Fast Neutron Activation Analysis (FNAA). This approach might replace Loss-on Ignition (LOI) as a conventional method for carbon analysis. Climate effects on physical and biological marine processes have been demonstrated as historical changes in carbon flux to sediments taken in the Western Black Sea at depths up to $22 \mathrm{~m}$. Carbon in sediments has been found in the form of the organic carbon produced by photosynthetic organisms and as inorganic carbon produced by calcifying organisms and precipitated as calcite.

Acknowledgments We are grateful to the JSS Editor-in-Chief Prof. Phil Owens and Editorial Managers Ms. Moira Ledger and Mr. Jesson Austria for their outstanding support in managing the manuscripts of this special issue.

\section{References}

Baran A, Mierzwa-Hersztek M, Urbaniak M, Gondek K, Tarnawski M, Szara M, Zieliński M (2019) An assessment of the concentrations of PCDDs/Fs in contaminated bottom sediments and their sources and ecological risk. J Soils Sediments. https://doi.org/10.1007/s11368019-02492-3 (this issue)

Cecchi G, Cutroneo L, Di Piazza S, Vagge G, Capello M, Zotti M (2020) From waste to resource: mycoremediation of contaminated marine sediments in the SEDITERRA project. J Soils Sediments. https:// doi.org/10.1007/s11368-019-02527-9 (this issue)

Garcia-Blas N, Jimenez-Relinque E, Nevshupa R, Castellote M (2020a) Interaction dynamics between a contaminated dredged sediment and extracting solutions of different nature. J Soils Sediments:20. https:// doi.org/10.1007/s11368-019-02466-5 (this issue)

Garcia-Blas N, Jimenez-Relinque E, Nevshupa R, Castellote M (2020b) Electrokinetic approach to assess the behaviour of a contaminated marine sediment. J Soils Sediments. https://doi.org/10.1007/s11368020-02615-1 (this issue)

Joksimović D, Perošević A, Castelli A, Pestorić B, Šuković D, Đurović D (2020) Assessment of heavy metal pollution in surface sediments of the Montenegrin coast: a 10-year review. J Soils Sediments. https:// doi.org/10.1007/s11368-019-02480-7 (this issue)

Kirichek A, Shakeel A, Chassagne C (2020) Using in situ density and strength measurements for sediment maintenance in ports and waterways. J Soils Sediments. https://doi.org/10.1007/s11368-02002581-8 (this issue)

Knežević L, Cukrov N, Bura-Nakić E (2020) Ion-exchange chromatography as a tool for investigating vanadium speciation in sediments: preliminary studies. J Soils Sediments. https://doi.org/10.1007/ s11368-019-02484-3 (this issue)

Lecomte T, Mamindy-Pajany Y, Lors C, Lemay M, Abriak NE, Christine Bazin C, Vernus E (2020) A methodological approach for ecotoxicological characterization of non-hazardous sediments for their beneficial reuse. J Soils Sediments. https://doi.org/10.1007/s11368-01902543-9 (this issue)

Lehoux AP, Petersen K, Leppänen MT, Snowball I, Olsen M (2020) Status of contaminated marine sediments in four Nordic countries: assessments, regulations, and remediation approaches. J Soils Sediments. https://doi.org/10.1007/s11368-020-02594-3 (this issue)

Obhodas J, Tinivella U, Giustiniani M, Durn T, Vinkovic A, Radic S, Soprun F, Sudac D (2020) Past and present potential of the Adriatic deep sea sediments to produce methane hydrates. J Soils Sediments. https://doi.org/10.1007/s11368-019-02497-y (this issue) 
Pellegrini M, Abbiati M, Bianchini A, Colangelo MA, Guzzini A, Mikac B, Ponti M, Preda G, Saccani C, Willemsen A (2020) Sustainable sediment management in coastal infrastructures through an innovative technology: preliminary results of the MARINAPLAN PLUS LIFE project. J Soils Sediments. https://doi.org/10.1007/s11368019-02546-6 (this issue)

Romano E, Bergamin L, Pierfranceschi G, Chiara Maggi C, Berducci MT, Ausili A (2020) Conflicting outcomes of an integrated approach to sediment quality assessment in a Sardinian coastal area subjected to mining activities. J Soils Sediments. https://doi.org/10. 1007/s11368-019-02489-y (this issue) activities

Shakeel A, Kirichek A, Chassagne C (2020) Rheological analysis of mud from Port of Hamburg, Germany. J Soils Sediments. https://doi.org/ 10.1007/s11368-019-02448-7 (this issue)

Szalińska E, Orlińska-Woźniak P, Wilk P (2020) Sediment load variability in response to climate and land use changes in a Carpathian catchment (Raba River, Poland). J Soils Sediments. https://doi.org/ 10.1007/s11368-020-02600-8 (this issue)

Tamburrino S, Passaro S, Manta DS, Quinci E, Ausili A, Romano E, Sprovieri M (2020) Re-shaping the "original SIN": a need to rethink sediment management and policy by introducing the "buffer zone" concept. J Soils Sediments. https://doi.org/10.1007/s11368019-02486-1 (this issue)
Valkovic V, Obhodas J (2020) Sediments in the ship's ballast water tank: a problem to be solved. J Soils Sediments. https://doi.org/10.1007/ s11368-020-02624-0 (this issue)

Vauclin S, Mourier B, Tena A, Piégay H, Winiarski T (2020) Effects of river infrastructures on the floodplain sedimentary environment in the Rhône River. J Soils Sediments. https://doi.org/10.1007/s11368019-02449-6

Vinković A, Obhođaš J, Sudac D, Nađ K, Valković V (2020) Analysis of carbon in sediments using fast neutron activation analysis (FNAA). J Soils Sediments 20. https://doi.org/10.1007/s11368-019-02485-2 (this issue)

Zander F, Heimovaara T, Gebert J (2020) Spatial variability of organic matter degradability in tidal Elbe sediments. J Soils Sediments. https://doi.org/10.1007/s11368-020-02569-4 (this issue)

Zeraoui A, Benzerzour M, Maherzi W, Mansi R, Abriak NE (2020) New software for the optimization of the formulation and the treatment of dredged sediments for utilization in civil engineering. J Soils Sediments. https://doi.org/10.1007/s11368-020-02605-3 (this issue)

Publisher's note Springer Nature remains neutral with regard to jurisdictional claims in published maps and institutional affiliations. 